\title{
Dergiabant
}

Cilt/Volume: 9, Sayı/Issue: 2

(Kasım/November 2021)

\section{Arap Edebiyatında Vasiyet Türleri: Sadrü'l-İslâm Dönemi}

\author{
Testaments in Arab Literature: Șadr al-Islam (The \\ Golden Age of Islam) Period
}

\author{
Ebubekir Matpan \\ Öğr. Gör., İnönü Üniversitesi, İlahiyat Fakültesi, \\ Arap Dili ve Belâgatı Anabilim Dalı \\ Lecturer, Inonu University, Faculty of Theology, \\ Department of Arabic Language and Rhetoric \\ Malatya/Turkey \\ ebubekir.matpan@inonu.edu.tr \\ orcid.org/0000-0002-3571-5087

$\underline{\text { Makale Bilgisi } \quad \text { Article Information }}$

Makale Türü: Araştırma Makalesi

Geliş Tarihi: 24 Ağustos 2021

Kabul Tarihi: 23 Kasım 2021

Yayın Tarihi: 30 Kasım 2021

Yayın Sezonu: Güz
Article Type: Research Article

Date Received: 24 August 2021

Date Accepted: 23 November 2021

Date Published: 30 November 2021

Publication Season: Autumn

https://doi.org/10.33931/dergiabant.986732

$*$

\section{İntihal/Plagiarism}

Bu makale özel bir yazılımla taranmış ve intihal tespit edilmemiştir.

This article was scanned with a special software and no plagiarism was detected.

\section{Atıf/Cite as}

Matpan, Ebubekir. “Arap Edebiyatında Vasiyet Türleri: Sadrü'l-İslâm Dönemi”. Dergiabant 9/2

(Kasım 2021), 766-782. https://doi.org/10.33931/dergiabant.986732

Copyright $\odot$ Published by Bolu Abant Izzet Baysal University Faculty of Theology, Bolu, 14030 Turkey. All rights reserved. https://dergipark.org.tr/tr/pub/dergiabant 


\title{
Arap Edebiyatında Vasiyet Türleri: Sadrü'l-İslâm Dönemi
}

\begin{abstract}
Öz
Vasiyetin tarihi insanlık tarihi kadar eskidir, insanoğlu var olduğu günden beri vasiyet de edebiyattaki yerini almıştır. Kur'an'ı Kerim de bazı peygamberlerin çocuklarına vasiyetlerde bulunduğunu aktarır. Vasiyet sanatı, kaliteli şekil ve üslubuyla öne çıkan bir edebiyat türüdür. Vasiyette kişi yaşamı boyunca kazandığı tecrübe ve birikimlerini başkasına aktarır. Câhiliye döneminde de vasiyet bilinen bir edebi türdü. İslâm devletinin kurulup genişlemesinden sonra ortaya çıkan yeni durumlar neticesinde vasiyet türlerinde artış meydana gelmiş, önceden var olmayan birtakım konular eklenerek genișlemiștir. Bu çalışmada önceden var olan bu edebiyat türüyle beraber ortaya çıkan yeni vasiyet türleri de ele alınmıștır. Bu zaman dilimindeki vasiyetler, Hz. Muhammed'in (sav) önderliğinde yeni bir boyut kazanmış ve Müslümanların hayatını içine alan bir tür olarak yoluna devam etmiş̧tir. Hz. Muhammed'den (sav) sonra da İslâm coğrafyası genişlemiş, râş̧it halifeler vasiyeti hayatın tüm alanlarına yayarak Sadrü'l İslâm döneminin en güzel örneklerini vermelerini sağlamıştır. Yapılan araştırmalar neticesinde Sadrü'l İslâm döneminde vasiyet türlerini müstakil olarak ele alan bir çalışmanın bulunmaması, elimizdeki makalenin ortaya çıkmasını sağlamıştır. Bu çalışmada bahsi geçen dönem ile ilgili vasiyet türlerinin tespiti yapılmıştır. Makalede öncelikle Sadrü'l İslâm döneminin hangi zaman dilimini kapsadığı, daha sonra vasiyetin sözlük ve terim anlamı verilmiștir. Sonrasında Sadrü'l İslâm dönemi vasiyet çeșitleri ele alınmış, vasiyetin genel özellikleri de kısaca anlatıldıktan sonra sonuç kısmıyla çalışma tamamlanmıştır.
\end{abstract}

Anahtar Kelimeler: Edebiyat, Arap Dili ve Belagatı, Sadrü’l-İslâm, Nesir, Vasiyet.

\section{Testaments in Arab Literature:}

\section{Șadr al-Islam (The Golden Age of Islam) Period}

\begin{abstract}
The history of the testament is as old as the history of humanity, the testament has existed since the day human beings existed. The Qur'ān states that some prophets made bequests to their children from time to time. Testament art is a type of literature that stands out with its quality form and style. In a testament, the person transfers the experience and knowledge he has gained throughout his life to someone else. Testament was a well-known literary genre in the period of ignorance of the Arabs before Islam. In the period of Șadr al-Islam, the testament experienced its brightest period as a result of new situations that emerged after the expansion of the Islamic state. The testaments have gained a new format under the leadership of the Prophet Muhammad (pbuh). After the Prophet Muhammad (pbuh), the Islamic geography expanded, and the Rāshidūn caliphs spread the testament to all areas of life, this has enabled them to give the best examples of the Sadr al-Islam period. As a result of the researches, the absence of a study dealing with the types of testaments in the period of Șadr al-Islam has led to the emergence of this article in our hands. In this article, the types of wills of the Sadr al-Islam period were discussed, the general characteristics of the testament were briefly explained, and the study is completed with the conclusion part.
\end{abstract}

Keywords: Literature, Arabic Language and Rhetoric, Șadr al-Islam, Prose, Testament. 


\section{Giriş}

Vasiyetin tanımı, çeşitleri ve özelliklerine geçmeden önce çalışmanın daha iyi anlaşılmasına katkı sağlayacağı düşünülerek, Sadrü'l İslâm döneminin hangi tarihte başlayıp ne zamana kadar devam ettiği açıklanmaya çalışılacaktır.

Sadrü'l-İslâm Dönemi, mîlâdî 7. yüzyılda İslâm dininin Hz. Muhammed'e (sav) M. 610 senesinde vahyedilmesiyle beraber başlayan, IV. Halife Hz. Ali'nin (ra) (öl. 41/661) M. 661 / H. 41 şehit edilmesiyle sona eren döneme verilen isimdir. Sadrü'l-İslâm dönemi ayrıca kendi içerisinde ikiye ayrılmaktadır: Birincisi, Hz. Peygamber'e tebliğ vazifesinin verildiği tarih olan M. 610 yılında başlayan ve M. 632 / H. 10 yılında Medine'de vefat ettiği tarihe kadar ki dönemdir. İkincisi ise; Hz. Ebubekir'in (ra) (öl. 13/634) M. 632 / H. 10 yılında halife seçilmesiyle başlayıp Hz. Ali'nin (ra) M. 661 / H. 41 şehit edilmesiyle son bulan dönemi kapsamaktadır. ${ }^{1}$

İslâm'ın, Arap Yarımadasına gelişiyle birlikte, bütün alanlarda köklü değişiklikler meydana gelmiştir. Bu alanlardan biri de edebiyat olmuştur. Kur'an'ı Kerim'in, şiir olarak değil de nesir olarak Arap toplumuna indirilmesi nesir ve türlerinin ön plana çıkmasına öncülük etmiştir. Ayrıca bu üslup, Kur'an'ın emir ve yasaklarını yeni topluma açıklamak için vasita olmuştur. İslâm dininin gelmesiyle beraber, Câhiliye döneminde mevcut olan bazı nesir türleri, bu dönemde itibar görmemiştir. Özellikle de İslâm'ın yasakladığı, kâhinlerin secili sözleri (سجع الكهان), intikam alma, din ile ilgili olmayan veya dinin tasvip etmediği hususlar vb. nesir konuları, yeni dinin öğretileri karşısında tutunamamıştır. ${ }^{2}$

Yukarıda ifade edilen türlerinin dışında, câhiliye döneminde var olan bazı konular, bu dönemde de varlığını sürdürmüștür. Bunlar, vasiyet, hitâbet, kitâbet, ${ }^{3}$ meseller ve hikmetli sözler olarak isimlendirilen nesir türleridir. $\mathrm{Bu}$ çalışmada vasiyet kısmı açıklanmaya çalışılacaktır.

\section{Vasiyet'in Tanımı}

İslâm dini gelmeden önce var olan vasiyet, İslâm geldikten sonra da varlığını devam ettirmiş hayat şartlarının değişmesine bağlı olarak Câhiliye döneminden farklı olarak birçok alanı da içine alan yeni bir nesir türüne dönüşmüştür.

Vasiyetin çoğulu و- و ص- ي . kökünden türeyen ve isim olan bu kelime sözlükte, "vasiyet, Ismarlanan şey, öğüt ve tavsiye,4 birisine bir konuda öğüt vermek,

1 Muhammed Abdulmun'im Hafâcî, el-Hayâtü'l-edebiyye ba'de zuhûri'l-İslâm (Beyrut: Dârü'l-Cîl, 1990), 8.

2 Ebubekir Matpan, "Arap Edebiyatında Tevkîât (Sadru'l-İslâm Dönemi)", Mesned Illahiyat Araştırmaları Dergisi 12/1 (30 Haziran 2021), 78.

3 Câhiliye döneminde Kitâbet sadece Arabistan'ın kuzey bölgesinde yaşayan Araplar tarafından bilinmekteydi. Bu nesir türü diğer bölgelerde kendisine varlık bulamamıștır. Muhammed Selim İpek, Klasik Dönem Arap Edebiyatında Nesir (Gece Kitaplığı, 2015), 49.

4 Muhammed b. Ya'kûb Fîrûzâbâdî, el-Kâmûsü'l-muhît, thk. Yusûf el-Bîkâî (Beyrut: Dârü'l-Fikr, 1995), "vsy" 1208. 
tavsiyede bulunmak, talimat vermek, görevlendirmek"5 gibi anlamlara gelmektedir. Vasiyet kelimesinin kökünde "ulaştırmak" manası vardır, çünkü kişi başkasına vasiyette bulunarak kendi bilgi ve becerilerini ona ulaştırır, onun bilgi sahibi olmasını sağlar.

Arap edebiyatında eski bir nesir türü olan vasiyet, terim olarak da; "Bilgi ve tecrübe sahibi kimsenin, elde ettiği tecrübeleri ve bilgileri kendisinden sonraki nesillerin, hayatına yön vermek, davranışlarını düzenlemek ve onlara doğruyu göstermek için seçtiği anlamca tesirli, seçkin lafızlardır." ${ }^{6}$ şeklinde tanımlanmıştır.

Arap dili edebiyatında tavsiye/öğüt için vasiyet kelimesinin kullanımı yaygınlık kazanmıştır. Arapçada vasiyet kelimesinin iki kullanımı vardır. Bunlardan birincisi hayatta olanların birbirlerine yaptıkları vasiyettir. Türkçede bu ögüt olarak bilinir, ikincisi ise ölüm döşeğinde olanların ya da ölümün kendilerine yaklaştığını hisseden kişilerin kendilerinden sonra yapılmasını istedikleri șeylerle ilgili yaptıkları vasiyettir. ${ }^{7}$ Dilimizde vasiyet denilince akla ilk gelen ikinci kısımdır. Bu çalışmada vasiyet kelimesinin Arapçadaki kullanımı esas alınmıştır.

Vasiyetler, sıradan bir konuşma olmayıp, vasiyet sahiplerinin hayatta kazandıkları tecrübeleri ifade etme bakımından günlük konuşmalardan ayrılır. Vasiyetin amacı insanları ve içinde yaşadıkları toplumu iyiye, başarıya, hayatlarını kolaylaştırma ve güzele yönlendirmek olarak açıklanabilir. Arap edebiyatında vasiyet, başlı başına bir nesir türü olarak kabul edilir. 8 İnsan fitratı gereği, vasiyet etme ve alma eğilimine sahiptir. Bu nedenle, vasiyet tüm zaman ve mekânlarda varlığını devam ettiren bir nesir türü olarak karşımıza çıkmaktadır.

\section{Sadrü'l-İslâm Döneminde Vasiyet ve Türleri}

Giriş bölümünde bu dönemin sınırları belirtildiğinden burada tekrar etmeye ihtiyaç duyulmamıştır. İslâm'dan önceki Araplar, tamamen güzel huylardan uzak değillerdi. Câhiliye toplumu, cömertlik, izzet-i nefis, onur, öz saygı, müttefiklerini canları pahasına koruma, kendilerine sığınanları gözetme gibi övülmeyi hak eden erdem ve davranışlara sahip olan bir topluluktu. İslâm dini, bütün bunları bildiğinden onların övülmeye değer özelliklerini, güzel huylarını terk etmelerini istememiştir. Zira Câhiliye döneminde seçkin olan şahsiyetler, İslâm sonrası dönemde dinlerini öğrendiklerinde yine seçkin olmaya devam etmişlerdir. ${ }^{9}$ Tam da bu yüzden İslâm, Arapların önceki güzel huylarını, İslâm'ın öğretilerine ters düşmediği sürece olduğu gibi bırakmıştır.

5 Muhammed b. Ahmed el-Ezherî, Tehzîbüll-luga, thk. Abdusselâm Muhammed Hârûn (Kahire: Mektebetü'l-Hâncî, 1976), "vsy" 12/198.

6 Ömer Ferrûh, Târîhu'l-edebi'l-arabî (Beyrut: Dârü'l-ilm lil'melâyîn, 1981), 1/89; Muhammed b. Abdilmün 'im Hafâcî, el-Hayâtü'l-edebiyye fi'l-'asri'l-câhilî (Beyrut: Dârü'l-Cîl, 1992), 152.

7 Ebü'l-Hâris Necmüddîn Üsâme b. Mürşid b. Alî b. Mukalled b. Münkız, Lübâbi'l-âdâb (Msır: elMatba'tü'r-Rahmâniyya, 1953), 1.

8 İbrahim Fidan, Klasik Arap Edebiyatında öğütler (Ankara: Gece Kitaplı̆̆ı, 2017), 5.

9 Abdüşşâfî Muhammed Abdüllatîf, Âsru'n-nübüvve ve'l-hilâfet'r-râşide (Kahire: Şerîketü's-Sefîr, ts.), 8. 
Arapların, Câhiliye dönemindeki edebiyatına gelince, İslâm, özellikle şiiri kendi değerlerine uygun hale getirip, Cahiliye dönemindeki sakıncalardan arındırdıktan sonra kabul etmiş, bununla yetinmeyip onu düşmanlarına karşı etkili bir biçimde de kullanmıştır. ${ }^{10}$ Şiir dıșında kalan diğer nesir türlerini de kâhinlerin uydurma sözleri dışında kalanları kabul ettikten sonra kendi karakterine dönüştürüp, İslâmi kisveyle onları kullanmıştır.

Çalışmanın konusu olan vasiyete gelince, Arapların İslâm'dan önce de bu nesir türünü bildikleri kaynaklarda geçmektedir. Câhiliye dönemine ait birçok vasiyet örneği günümüze ulaşmıştır.11 İslâm döneminde, hem Hz. Peygamber (sav) hem de dört halife ve sahâbenin vasiyetleri tarihi vesikalarda yer almıştır.

İslâm dönemindeki de vasiyetler, Câhiliye de olduğu gibi lafız ve mana cihetiyle paralellik arz eder. ${ }^{12}$ Ancak vasiyet, İslâm'dan sonra kendine özgü yeni bir yöntem çizmiş, şekil ve içerik olarak Kur'an ve İslâm'ın öğretilerinin öne çıktığı bir yolda ilerlemiş̧tir. Bu dönemde vasiyetler Câhiliye dönemindeki konuları da içine alarak daha çok doğruluk, adalet, şükür, hayâ, takva, sâlih amel, sır tutma, akrabayı gözetme, tevekkül, kanaatkâr olma, iyiliği emretme ve kötülükten alıkoyma vb. konulara yoğunlaşarak geniş bir içeriğe sahip olmuştur.

Sadrü'l-İslâm dönemindeki vasiyet çeşitlerine geçmeden önce, onunla Hitabet arasındaki farka kısaca değinmekte fayda vardır. İkisi arasındaki fark üç maddede şöyle açıklanabilir:

a) Hutbe, sanatında hutbenin giriş, gelişme ve sonuç bölümleri olur. Vasiyette ise bunlar yoktur.

b) Vasiyette, söylenen söz devlet başkanı, baba gibi faklı kişilerden yapılan sözlü ya da yazılı mektupla da olabilir, hitabet ise sözlü olarak icra edilir.

c) Hitabet sanatını, o konuda liyakat sahibi olan insanlar yapabilir, vasiyeti ise herkes tarafından yapılabilir. ${ }^{13}$ Bundan da anlaşıldığı üzere, vasiyet ile hitabet birbirinden farklı iki edebiyat türüdür.

Sadrü'l-İslâm Dönemindeki vasiyetleri, ihtiva ettiği konular bakımından beş başlık altında incelemek mümkündür. Bunlar:1) Dini Vasiyetler, 2) Siyasi Vasiyetler, 3) Askeri Vasiyetler, 4) Sosyal Vasiyetler, 5) Ticaret İlişkileri ile İlgili Vasiyetlerdir. Şimdi de bu vasiyet türleri incelenecektir.

\section{Dini Vasiyetler}

Dini vasiyetler, şüphesiz ki Sadrü'l-İ́slâm döneminde edebiyat konusunun başında gelmektedir. Bu durum gayet doğaldır, zira Arapların hayatındaki en büyük değişiklik, İslâm

10 Ahmet Kâzım Ürün, Klasik Arap Edebiyatı (Konya: Çizgi Kitapevi, 2015), 61-62.

11 Câhiliye dönemindeki vasiyetler için bk. Ebü'l-Ferec Alî b. el-Hüseyn b. Muhammed b. Ahmed el-Kureșî el-İsfahânî, el-Eğâni (Kahire: Dâru İhyâü't-Türâsi'l-Ârabî, 1963), 11/40; Hafâcî, elHayâtü'l-edebiyye fi'l-'asri'l-câhilî, 150-151.

12 Kenan Demirayak, Arap Edebiyatı Tarihi-II, Sadru'l-İslâm Dönemi (Erzurum: Fenomen Yayınları, 2017), 1/237.

13 Demirayak, Arap Edebiyatı Tarihi-II, Sadru'l-İslâm Dönemi, 1/237. 
ile başlamıştır. İslâm, bütün alanlarda köklü reformlar meydana getirmiş, dünyanın fani ve ahiret hayatı için bir geçiş dönemi, oyun ve eğlenceden ibaret olduğunu, gerçek hayatın ise yalnızca ahiret yurdunda bulunduğu gerçeğini anlatmıștır. Kur'an'ı Kerim insanoğlunun

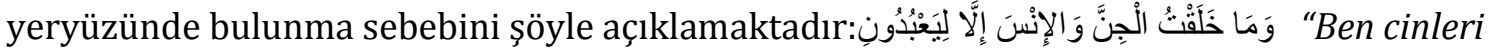
ve insanları, anacak bana kulluk etsinler diye yarattım."14 Ayrıca Kur'an'ı Kerim zaman

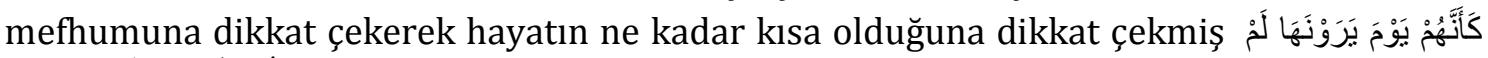

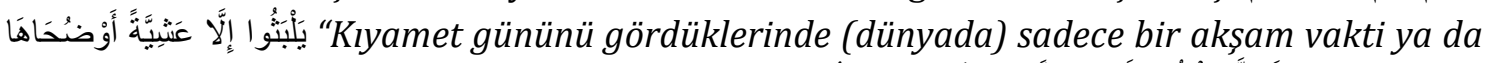

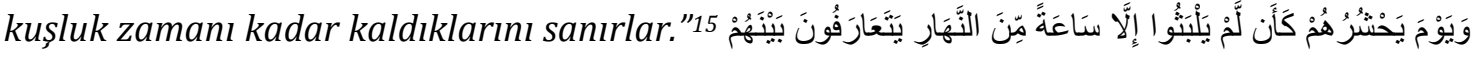
"Allah'ın onları, sanki günün ancak bir saati kadar kaldıklarını zanneder vaziyette yeniden diriltip toplayacağı gün aralarında birbirleriyle tanışırlar." $16 \mathrm{Bu}$ ve daha birçok ayette buna dikkat çekerek nefisleri dünya kirinden arınmaya teşvik etmiş, Müslümanların hayatına yön veren tavsiyelerin ortaya çlkmasına vesile olmuştur.

Dini vasiyetler kendi içinde birçok kısma ayrılmaktadır. Ancak dini vasiyetlerin çeşitlerine geçmeden önce iki konuya işaret etmekte fayda vardır. Şöyle ki;

a) Dini vasiyetler, şer'i mirasla ilgili kısımdan farklı olup, bir edebiyat türüdür.

b) Dini vasiyetler denildiğinde, buradaki amaç dini öğütlerin bizzat kendisidir. Yoksa Sadrü'l-İslâm dönemindeki bütün vasiyetler, konusu ne olursa olsun bu başlık altına girer. Burada bu ayırıma gitmedeki amaç, yalnızca çalışmanın sınırlarını belirtmektir. ${ }^{17}$ Sadrü'l-İslâm döneminde dini vasiyetler şu şekillerde karşımıza çıkmaktadır:

\subsection{Hz. Peygamberin Ümmete ya da Belli Bir Guruba Yaptığı Vasiyetler}

$\mathrm{Bu}$ türden vasiyet çeşitleri, sahabeden birinin Hz. Muhammed'e (sav) gelip kendisine ögüt vermesini, ya da Hz. Muhammed'in (sav) ümmetinin fertlerine veya tamamına yaptığı tavsiyelerdir. Bir defasında sahâbeden biri Hz. Muhammed'e (sav) gelerek şöyle demiş̦tir: " "Ey Allah’ın Resûlü! İslâmiyet hakkında bana bir öğüt veriniz ki, sizden sonra artık kimseye bir şey sormaya ihtiyacım kalmasın" bunun üzerine Peygamber (sav); " ققل آمنت باله ثم استقم" "Allah'a iman ettim de sonra da dosdoğru ol"18 buyurmuştur. Buna benzer tavsiyelerin örnekleri hadis külliyatında oldukça fazladır. Bunun yanı sıra, hiç soru olmadan Hz. Muhammed'in (sav) ümmetine tavsiyede bulunduğu hadislerde çoktur. Bir tavsiyesinde Hz. Muhammed (sav), ümmetine

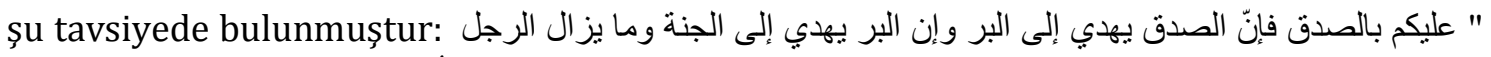

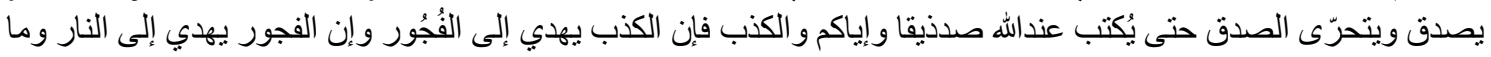

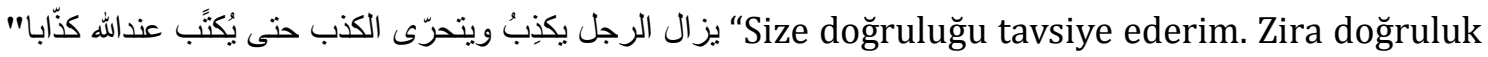
iyiliğe götürür, iyilikte cennete iletir. Kişi doğru söyledikçe, doğruyu araştırdıkça, Allah katında doğrun yazılır. Yalandan kaçının, zira yalan kötülüğe götürür, kötülük de cehenneme iletir. Kişi yalan söyledikçe ve yalan peşinden gittikçe Allah katında yalancı

ez- Zâriyât, 51/56.

en-Nâziât, 78/46.

Yûnus, $10 / 45$.

Ali Hüseyin Muhammed et-Temr, "el-Vesâyâ fî asr sadri'l-İslâm", Mecelltü câmiat Tikrît li'lulûm 20/1 (2012), 219.

18 Ebü'l-Hüseyn Müslim b. el-Haccâc b. Müslim el-Kuşeyrî, el-Câmi'u's-sahîh (Beyrut: Dâru İhyâi'lKütübi'l-Arabiyye, 1991), “İman”, 13. 
yazılır."19 Bu tür vasiyete örnek olacak güzel vasiyetlerden biri de, Hz. Muhammed'in (sav) Veda Haccında ümmetine yaptığı tavsiyelerdir. Ayrıca münafıklığın alametinin üç olduğunun ifade buyurduğu hadisi ${ }^{20}$ ve daha birçok hadisi bu başlık altında zikretmek mümkündür.

\subsection{Hz. Peygamberin Şahıslara Yaptığı Tavsiyeler}

Bu tür vasiyetler, daha çok Hz. Muhammed'in (sav) ümmetinin fertlerine yönelik olup, bizzat kendisinin uygun gördüğü zamanda ve belirli kişilere yönelik yaptığı tavsiyelerdir. Bunlar özelde bir kişiye söylenmiş olsa da genel anlamda Müslüman toplumun tamamını ilgilendiren ve onların aktarmasıyla bütün ümmet için geçerli olan tavsiyelerdir. Buna örnek olarak aşağıdaki vasiyeti vermek mümkündür:

Hz. Muâz b. Cebel (ra) (öl. 17/638) diyor ki bir gün Hz. Muhammed (sav) elimden

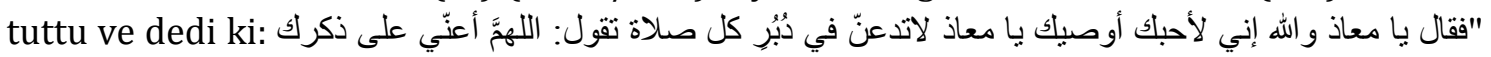
"Ey Muâz! Vallahi ben seni seviyorum. Her namaz sonunda: Allah'ım, sana şükretmek, sana güzelce ibadet etmek için bana yardım et, duasını bırakmamanı tavsiye ederim."21

Yine Hz. Muhammed 'in (sav), Hz. Abdullah b. Ömer'e (ra) (öl. 73/693) 'dünyada bir yolcu gibi yaşamasıyla' ilgili olan tavsiyesi bu konuya örnektir. Bu tavsiyede Hz. Peygamber (sav) şöyle buyurmuştur:" كن في الدنيا كأنّك غريب أو عابر سبيل وعُدّ نفسك من اهل القبور "Dünyada sanki gurbette imiş gibi veyahut yolculukta bulunuyormuş gibi ol. Kendini mezarlıktakilerden kabul et."22 Bu türden vasiyetler, hadis külliyatında çoktur. Biz burada örnek olması açısından birkaçını zikretmekle yetiniyoruz.

\subsection{Devlet Başkanının Tebaaya Vasiyetleri}

Bu çeşit vasiyetler, Sadrü'l-İslâm döneminde İlk Halife Hz. Ebubekir (ra) ile başlamış ve çok geniş bir alana yayılmıştır. Hz. Ebubekir (ra), ordu komutanlarına, ${ }^{23}$ kendisinden sonra yerine tayin ettiği Hz. Ömer'e (ra) (öl. 23/644), ${ }^{24}$ ve Müslümanlara çeşitli vasiyetlerde bulunmuştur. Ondan sonra da bu gelenek devam etmiş ve halifeler bu çeşit vasiyetleri geride kalanlara miras bırakmışlardır. Bu konuya şu vasiyet güzel bir örnektir: Hz. Ömer

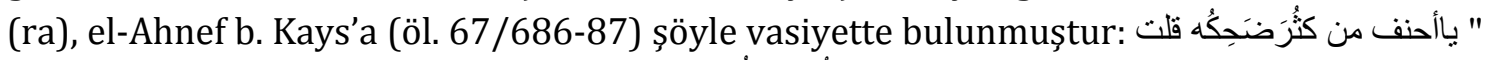

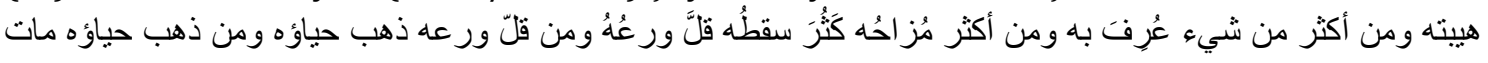
قلبه"

\footnotetext{
19 Müslim, "Birr", 29.

20 Ebû Abdillâh Muhammed b İsmail el-Buhâri, el-Câmicu's-sahîh (İstanbul: el-Mektebetü’lİslamî, 1979), “İman”, 24.

21 Ebû Dâvûd Süleyman b el-Eş'as b İshak es-Sicistani el-Ezdi, es-Sünen (Beyrut: Dâr İhyâu'sSünneti'n-Nebeviyye, 1988), "Salat”, 361.

22 Ebû Îsâ Muhammed b. Îsâ b. Sevre et-Tirmizî, el-Câmi`u's-sahîh (Kahire: Dârü'l-Meâ'rif, 1975), "Zühd", 25.

23 Muhammed el-Hudarî, İtmâmü'l-vefầ fî sîreti'l-hulefâ (Dımaşk: Dâr ibn kesîr, 1997), 43-44.

24 Ebû Osmân Amr b. Bahr b. Mahbûb el-Câhiz el-Kinânî, el-Beyân ve't-tebyîn (Beyrut: Dârü'lKütübi'l-İlmiyye, 2009), 2/30-31.
} 
"Ey Ahnef! Çok gülenin heybeti azalır. Bir şeyle çok uğraşan kişi onunla tanınır. Çok şaka yapan çok basitleşir. Basitleşen kişinin ise Allah'tan korkusu azalır. Allah'tan korkusu azalanın da hayâ duygusu gider. Hayâ duygusunu yitirenin kalbi ölür."25

\subsection{Devlet Başkanı ile Halk Arasındaki Karşılıklı Vasiyetler}

Bu çeşit vasiyetler, Sadrü'l-İslâm döneminde ortaya çıkmış olup, daha önce câhiliye döneminde olmayan bir vasiyet çeşididir. Bu vasiyet çeşidi, Kur'an'ı Kerim'in tavsiyesi ve و العصر : etkisiyle ortaya çıkmıştır. Zira Kur'an'ı Kerim'de Cenabı-ı Allah şöyle buyurmaktadır

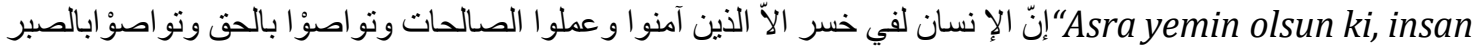
gerçekten ziyan içindedir. Bundan ancak iman edip iyi ameller işleyenler, birbirlerine hakkı tavsiye edenler ve sabrı tavsiye edenler müstesnadır."26 Buna örnek olarak Hz. Ömer'in (ra) halifeliği döneminde, Ahnef b Kays'in, halifeye şu şekilde tavsiyede bulunduğunu

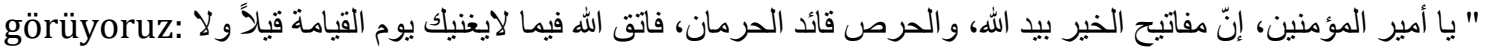
"Ey Müminlerin emiri! Hayrın anahtarı Allah'ın elindedir, hırs haramlara sürükleyendir, Kıyamet günün de sana fayda sağlamayacak boş sözlerden Allah'tan kork..."27 yine bu kabilden Hz. Ebubekir'in (ra) İslâm ordusunu Şam bölgesinin fethi için gönderdiğinde onları Medine'nin dışında durdurup bu yolculuk esnasında uymalarını istediği on şeyi kendilerine hatırlattığı vasiyeti de bu başlığın altında zikretmek mümkündür. ${ }^{28}$

\section{Siyasi İçerikli Vasiyetler}

Bu çeşit vasiyetlerin kökü câhiliye dönemine dayanmaktadır. Câhiliye döneminde, kabilelerin birbirleriyle olan münasebetleri ve komşu devletlerdeki krallarla olan ilişkilerini anlatan çok sayıda vasiyet bulunmaktadır. ${ }^{29}$

İslâm dini geldikten sonra, yeni bir devlet tesis etmiş, bu yeni devletin idare mekanizması, yönetimi, kendisine komşu olan devletlerle ilişkilerini düzenlemesi, diğer devletlerin kendi sınırları içerisindeki durumunu, İslâm devletinde yaşamını sürdüren diğer dinlere mensup azınlıklarla ilgili düzenlemeleri, halifenin kendisinden sonra kimin yerine geçeceği ile ilgili düzenlemeleri ve bu konuda bilgi sahibi olunması gerekliliği gibi vasiyet türlerinin ortaya çıkmasına zemin hazırlamıştır. ${ }^{30}$ Bununla yeni devletin sağlam temeller üzerine kurulması sağlanmıştır. Sadrü'l-İslâm döneminde siyasi vasiyetler farklı şekillerde karşımıza çıkmaktadır:

\subsection{Devlet Başkanının Kendisinden Sonra Yerine Atadığı Kişiye/Kişilere Vasiyeti}

Hz. Muhammed'in (sav) vefatından sonra, Müslümanları, kimin temsil edeceği ile ilgili tartışmalar çıkmış, ensar ve muhacirler arasına Hz. Peygamber'in yerine kimin devlet

25 İbn Münkız, Lübâbi'l-âdâb, 17.; Fidan, Klasik Arap Edebiyatında öğütler, 56-57.

26 el-Asr, 103/1-3.

27 Muhammed Nâyıf ed-Dülemî, Cemheratu vesâya'l-Arab (Beyrut: Dârü'n-Nidâl, 1991), 2/325.

28 Vasiyetin tamamı için bkz. Hudarî, İtmâmü'l-Vefâ, 43.

29 Hafâcî, el-Hayâtü'l-edebiyye fi'l-'asri'l-câhilî, 150.

30 Temr, "el-Vesâyâ", 222. 
idaresine geçeceği ile ilgili tartışmalar meydana gelmiştir. Ancak daha sonra bunlar tatlıya bağlanarak, büyük bir fitnenin önüne geçilmiştir. Yaşanan bu tartışmalar, halifenin kendisinden sonra aynı durumdan korkması ve yerine halife tayin etmesi, bu vasiyet türünün ortaya çıkmasını sağlamıştır.

$\mathrm{Bu}$ vasiyet türüne örnek olarak, Hz. Ebubekir'in (ra) kendisine ölümün yaklaştığını hissettiği zaman yerine halife olarak tayin ettiği Hz. Ömer'e (ra) olan vasiyeti bu türe örnek bir vasiyettir. Bu vasiyet aşağıdaki gibidir:

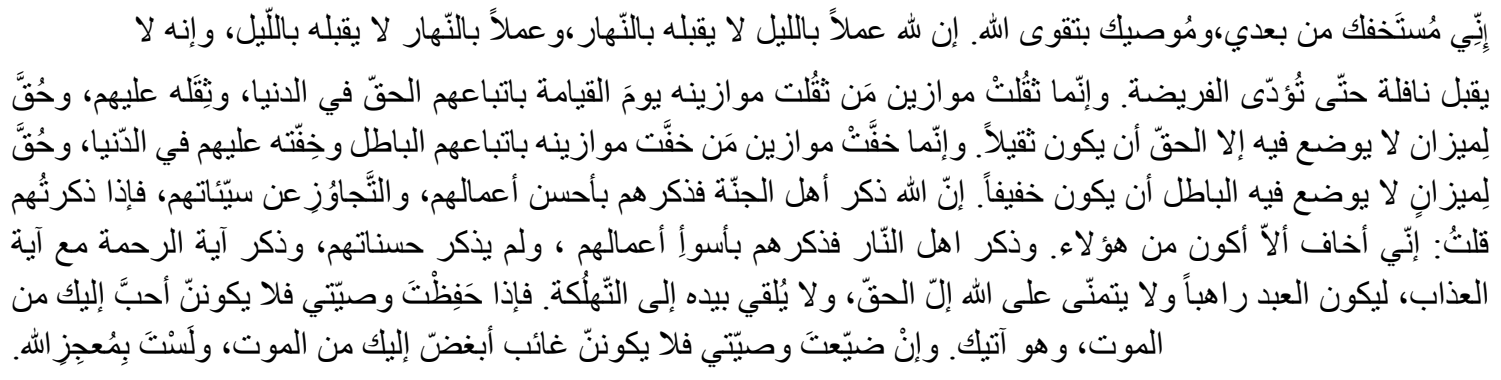

"Seni yerime halife tayin ediyorum. Allah'a (cc) karşı takvalı olmanı tavsiye ederim. Allah'ın geceye özgü ibadetleri vardır, onları gündüz kabul etmez. Gündüze özgü ibadetleri vardır, onları da gece kabul etmez. Farz yerine getirilmeden, nafileyi kabul etmez. Şüphesiz dünyada iken hakka uymaları sebebiyle kıyamet gününde terazileri ağır gelenlerin terazisi ağır gelir. Zira içerisin haktan başka bir şey bulunmayan terazinin ağır gelmesi kaçınılmazdır. Batıla uymaları sebebiyle de kıyamet gününde terazileri hafif gelen kimselerin terazisi de hafif gelir. Zira içerisinde batıldan başka bir şey bulunmayan terazinin hafif gelmesi kaçınılmazdır. Allah cennet ehlini anıyor. Onları en güzel amelleriyle ve günahlarının bağışlanacağını anlatıyor. Onları andığımda onlardan olmamaktan korkarım. Allah cehennem ehlini anlatırken de onların en kütü amellerini anlatır ve onların sevaplarını anlatmaz. Onları andığımda da onlardan olmamayı isterim, kul ümit ve korku arasında olması, Allahtan yalnızca hakikati temenni etmesi, kendi eliyle kendini tehlikeye atmaması için rahmet ayetlerini azap ayetleriyle beraber zikretmiştir. Eğer tavsiyeme uyarsan sana gözükmeyen bir şey ölümden daha sevimli olmaz. Ki o ölüm sana gelecektir. Ancak tavsiyemi zayi edersen sana gözükmeyen bir şey ölümden daha kötü olmaz. Ve sen Allah'ı aciz bırakacak değilsin."31

Hz. Ömer'in(ra) kendisinden sonra halife olacak kişiye/kişilere oğlu Abdullah aracılığıyla yaptığı vasiyet de bu türe örnektir. ${ }^{32}$

\subsection{Devlet Başkanının Kâdılara/Hâkimlere Vasiyeti}

Adalet mekanizması şüphesiz her devletin en önemli kurumlarındandır. Onu düzenlemek ve hayata geçirmek, insan haklarına sayglı olan tüm devletlerin öncelikleri arasında yer alır. Zira adaletin hakkıyla yerine getirilmediği devletler kısa sürede yıkılmaya, yok olmaya mahkûm olurlar. Ayrıca bir devlette adalet mekanizmanın düzgün bir şekilde

31 Câhiz, el-Beyân ve't-tebyîn, 2/30-31; Hudarî, İtmâmü'l-vefâ, 89.

32 Vasiyetin tamamı için bkz. Câhiz, el-Beyân ve't-tebyin, 31-32. 
işlemesi, onu diğer alanlarda da başarılı kılar ve bu, uzun vadede devletin siyasi alanlarda başarılar kazanmasına zemin hazırlar.

Halifelerin kâdılara/ hâkimlere vasiyetleri, İslâm'ın öne çıkan önemli vasiyet türlerindendir. Zira adalet, İslam'ın sadece kendi tebaasına karşı değil bütün halkalara karşı emrettiği temel ilkelerindendir. Bu vasiyet türü, ilk olarak Hz. Peygamber'in (sav) Muâz b. Cebel'i (ra) Yemen'e hâkim olarak gönderdiğinde onunla yaptığı diyalog ve halifelerin kâdılara/ hâkimlere vasiyeti ile Sadrü'l-İ́slâm döneminde ortaya çıkmıştır. ${ }^{33}$

Hz. Peygamber'den (sav) sonra da halifeler onun yolunu takip ederek, İslâm beldelerine atadıkları hâkimlere, toplumda insanlar arasında hüküm verirken nasıl bir yol takip etmeleri gerektiğini anlatan birçok tavsiyede bulunmuşlardır. Bunlardan bir tanesi $\mathrm{Hz}$. Ömer'in(ra), Hz. Ebû Mûsâ el- el-Eş'arîye (ra) (öl. 42/662-63) yazdığı ve hüküm verirken takip etmesi gereken prensipleri anlattığı tavsiyesidir. Erken dönem İslâm tarihinde en detaylı şekilde hüküm verme konusunda yöntem öğreten vasiyet olarak kabul edilmiştir. Bu metnin uzun olması sebebiyle aşağıda Türkçesi verilecektir. Arapçasına ulaşmak için verilen metnin asli kaynağına müracaat edilmelidir. Hz. Ömer'in (ra) yaptığı tavsiye aşağıdaki gibidir.

"Şunu bil ki, sana bir dava getirildiği zaman tatbiki mümkün olmayan delillerin faydası olmaz. İnsanlara karşı şahsî münasebetlerinde ve adaletinde eşit muamele yap ki, kuvvetli senin nüfuzundan korksun, zayıf da adaletine sığınsın. Delil göstermek davacıya aittir. İnkâr edene yemin etmek düşer. Bununla beraber, Müslümanlar arasında barış yapmak da caizdir. Ancak helâli haram, haramı da helâl kılan sulh kötüdür. Bir davada hüküm verdikten sonra bu hükmün yanlışlığına kanaat getirdiğinde doğruya dönmekte tereddüt etme. Çünkü asıl olan doğruya ulaşmaktır ve bu esas, yanlışta devam etmekten daha hayırlıdır. Kur'an ve Sünnette açık bir hüküm bulamadığın hallerde hüküm vermekte zorluk çekersen, önce buna benzer davalar ve örnekler ara ve önündeki dava ile aralarındaki ortak yanları tespit et. Ondan sonra Kur'an ve hakka en yakın olduğunu umduğun fikre itimat et ve bu hususta özellikle dikkatli ol. Hak iddia edenlere bunu ispatlayabilmeleri için delil getirebilecekleri bir mühlet tanı. Bu süre zarfında delil getirebilirse lehte, aksi halde aleyhte hüküm vermen gerçeğe daha yakın ve şüpheden daha uzak olur. Müslümanlar, hukukî meselelerde birbirlerine lehte ve aleyhte şahitlik edip adaletin tecelli etmesine yardımcı olmalıdırlar. Ancak sabıkalı olanlar, yalancı şahitliği veya iftirası sabit olanlar ve soyu bilinmeyenler, bu iş için makbul kişiler sayılmaz. Çünkü Allah, insanların vicdanlarında olanları bilir, şahitlik ve yemin gibi tamamen vicdanî faktörlerle adaletin tecellisini sağlar. Davalara bakarken telâşa, çığırtkanlığa ve tarafların haysiyetini kırıcı davranışlara asla müsaade etme. Çünkü adaletin yerini bulması için sükûnet ve ciddiyet şarttır. Hakkın tecelli etmesi ise ilahî adaletin itibar kazanmasına sebep olur. Bir Müslümanın niyeti iyi ise Allah, onun insanlarla olan münasebetlerini ıslah eder. Ama içi başka dışı başka olursa, Allah ona musibet verir. Bu durumda hâkimin görevi Allah'ın rızık ve rahmet hazinelerinin kulları arasında adaletle dağıtılmasını sağlamaktır." ${ }^{34}$

33 Temr, "el-Vesâyâ", 222.

34 Câhiz, el-Beyân ve't-tebyîn, 2/32-33. 
Yine Hz. Ömer'in (ra) Kâdı Şurayh'a (öl. 77/697) hüküm verme konusunda şu şekilde yol gösterdiği bir vasiyeti de mevcuttur: "Derin tartışmalara girme hüküm meclisinde satma, satın alma, kızgınken iki kişi arasında hüküm verme." ${ }^{35}$ Ayrıca Hz. Ömer (ra), Muâviye b. Ebî Süfyân'ı (ra) (öl. 60/680) Şam'a gönderdiğinde yaptığı tavsiye de bu çeşit vasiyetlere örnektir. ${ }^{36} \mathrm{Bu}$ türden tavsiyeler kaynaklarda çoktur.

\subsection{Devlet Başkanının Valilere Vasiyetleri}

Bu tür vasiyet çeşitleri, halifelerin İslâm şehirlerine atadıkları valilere, halka nasıl davranmaları gerektiği konusunda takip etmelerini istedikleri yolu ve İslâm'ın öğretilerine uygun olanını takip etmeleri konusunda yaptıkları tavsiyelerdir. Bu türün temelini, Hz. Peygamber'in (sav), Hz. Muâz b. Cebel'i (ra) Yemen'e vali olarak gönderdiğinde yaptığı vasiyet oluşturmuştur. Bu vasiyet şu şekildedir:

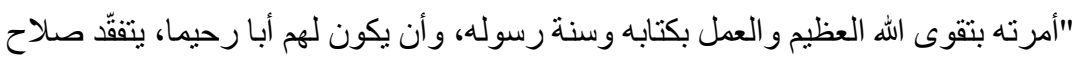

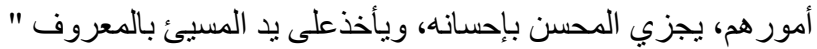

“Ona yüce Allah'tan sakınmasını, onun kitabıyla amel etmesini, halka karşı merhametli bir baba olmasını, onların işlerinin doğruluğunu kontrol etmesini; iyi olana iyilikle karşılık vermesini ve kötü olanı da iyiliğe zorlamasını emrettim". ${ }^{37}$

Hz. Peygamber'den (sav) sonra da halifeler bu geleneği devam ettirmiş ve atadıkları valilere bu türden tavsiyelerde bulunmuşlardır. Bunlardan birin de Hz. Ali'nin (ra) Hz. Abdullah b. Abbas'ı (ra) (öl. 68/687-88) Basra'ya vali olarak atadığında yaptığı vasiyettir.

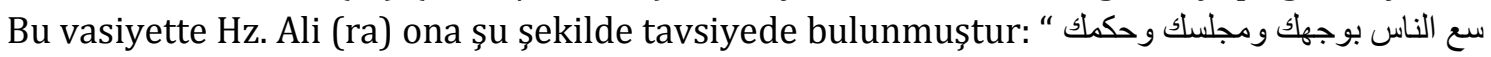
و إيّاّك و الغضب، فإنه طيرة من الثيطان واعلم أنّ ماقرّبك من الله يباعدك من النار، وما باعدك من الله يقربك من النار ““Karşılarken, meclisinde ağırlarken ve hüküm verirken İnsanları ferahlat. Öfkeden uzak dur. Çünkü o, şeytanın uğursuzluğudur ve bil ki seni Allah'a yakınlaştıran şey ateşten uzaklaştırır. Seni Allah'tan uzaklaştıran da ateşe yakınlaştırır."38

\subsection{Müslümanların Siyasi Konularda Kendilerini Temsil Edenlere Vasiyetleri}

Bu türden vasiyetler Sadrü'l-İslâm dönemi edebiyatının ürünüdür. Bu vasiyetlerin ortaya çıkmasına zemin hazırlayan sebeplerden birisi; Hz. Ali (ra) ile Hz. Muaviye (ra) arasında meydana gelen Sıffin savaşındaki meşhur "tahkim olayı"dır. Bu savaşta $\mathrm{Hz}$. Muaviye (ra) işler istediği gibi gitmeyince, Hz. Ali'den (ra) aralarında Allah'ın Kitabıyla hükmetmesi için hakem tayin etmeyi istemiş ve bu şekilde bu vasiyetler ortaya çıkmıștır.

Buna örnek olarak Ahnef b. Kays'ın) Hz. Ali'yi (ra) temsil etmek için görevlendirilen Hz. Ebû Mûsâ el-Eş'arî’ye (ra) yaptığı vasiyettir. Ahnef, Ebû Mûsâ'ya(ra) şöyle vasiyette

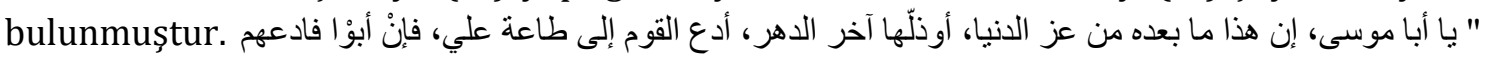

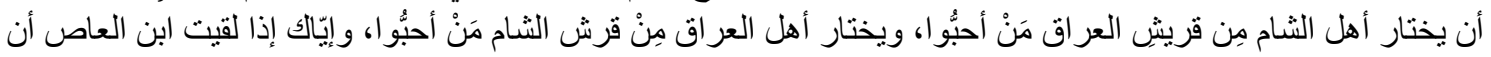

\footnotetext{
35 Dülemî, Cemheratu vesâya'l-Arab, 2/323.

36 Câhiz, el-Beyân ve't-tebyîn, 2/97-98.

37 İpek, Klasik Dönem Arap Edebiyatında Nesir, 99.

38 Ebu'l-Abbas Muhammed b. Yezid el-Müberred, el-Kâmil fi'l-edeb (Kahire: Dârü'l-Fikri'l-Ârabî, 1997), $1 / 13$.
} 


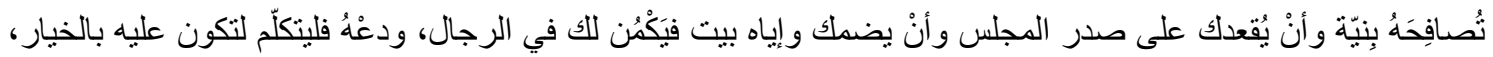

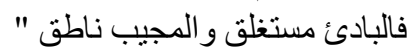

"Ey Ebû Mûsâ, bu işin sonu ya dünyanın şerefi ya da sonsuza kadar rezilliktir, halkı Hz. Ali'ye (ra) itaate davet et, eğer kabul etmezlerse, Şam halkını Irak'tan sevdikleri bir Kureyşliyi seçmelerine, Iraklıları da Şamdan sevdikleri bir Kuryeşli'yi seçmelerine davet et, İbnu'l-Âs (öl. 43/664) ile karşılaştığında ona dikkat et ve sakın onun elini samimiyetle sıkma. Seni toplantıda başköşeye oturtmasına da aldanma çünkü o hiledir. Sakın onunla aynı evde kalma ki sana adamlarla tuzak kurmasın ve ona ilk önce konuşma hakkını ver ki cevap vermede seçeneğin olsun. Zira başlayan zorlanır cevap veren ise konuşkandır". ${ }^{39}$

Ayrıca Hz. Ömer'in (ra) Utbe b. Gazvân'ı (ra) (öl. 17/638) Basra'ya vali olarak atadığında yaptığı vasiyet de bu türden bir vasiyet çeşididir.40

\subsection{Devlet Başkanlarının Meşru Düzene Karşı Çıkanlara Gönderdikleri Elçilere Vasiyetleri}

Halifeler, İslâm devletine başkaldıran, İslâm'ın emirlerini yerine getirmekten imtina edenlere, Allah'ın hükmünü bildirmek, onları yeniden doğru yola kazandırmak, savaşa başvurmadan, kan dökmeden önce kendilerinin yerine münazara adabını bilen, bu konuda tecrübeli olan, dili dönen, karşındakini ikna edebileceklerine inandıkları kişileri, muhalifleri yola getirmek için zaman zaman elçiler göndermişlerdir.

$\mathrm{Bu}$ türe verilecek vasiyet örneklerinden birisi de Hz. Ali'nin (ra) Siffîn savaşında yaşanan tahkim olayından sonra Hâricîler, kendisine karşı gelip, ${ }^{41}$ ona tabi olmayı reddetmişlerdir. Hz. Ali bu durumu düzeltmek için zaman zaman onlarla münazara etmek ve kendilerini doğru yola getirmek için Hz. Abdullah b. Abbas'ı (ra) gönderirken ona yaptığı

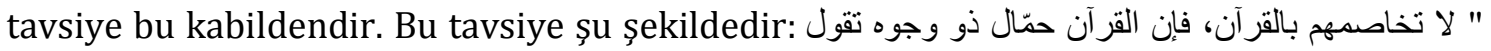
"Onlarla Kur’an ile tartışma, zira Kur’an’ın farklı vecihleri vardır sen bir yönünü söylersin onlar da başka bir yönünü. Ancak sen onlarla Sünnet ile mücadele et zira onlar ondan kaçacak yol bulamazlar. ${ }^{42}$

\section{Askeri Vasiyetler}

İslâm devleti kurulduktan sonra, her ne kadar düzenli ordu olmasa da hem $\mathrm{Hz}$. Muhammed (sav) hem de halifeler, gazveye çıkan ordu ve komutanına; İslâm'ın savaş kurallarını hatırlatmak, savaşın insan neslini yok etmek olmadığını, savaşın da bir ahlak içerisinde olması gerektiğini hatırlatarak, çocuk, ihtiyar ve kadınların öldürülmemesi; ağaçların kesilmemesi, gerekli durumlar da istişareye önem vermeleri vb. konularda gerekli hassasiyeti göstermeleri konusunda tavsiyede bulunmuşlardır.

39 Dülemî, Cemheratu vesâya'l-Arab, 2/323.

40 Dülemî, Cemheratu vesâya'l-Arab, 2/179-180.

41 Dinî ve siyasî konulardaki aşırı görüş ve faaliyetleriyle tanınan firka, bu konuda daha detaylı bilgi için bk. Ethem Ruhi Fı̆̆lalı, "Hâricîler" (İstanbul: Türkiye Diyanet Vakfı Yayınları, 1997), 16/169.

42 Dülemî, Cemheratu vesâya'l-Arab, 2/229. 
Hz. Muhammed'in (sav), Hz. Ali'yi (ra) Hayber'in fethine gönderdiği zamanki vasiyeti43; Hz. Ebubekir'in (ra), Hz. Üsame b. Zeyd'i (ra) (öl. 54/674) Hz. Peygamber'in (sav) vefatından hemen sonra Suriye'ye gönderirken yaptığı vasiyet bu konuda dikkat çekici,

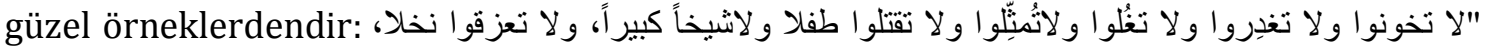

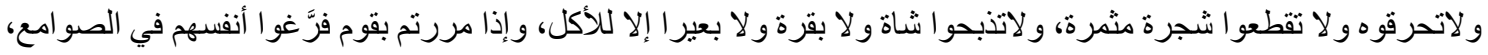

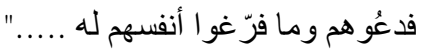

"Hainlik etmeyin, sözünüzden dönmeyin, kin tutmayın ve öldürdüklerinizin uzuvlarını kesmeyin. Çocukları, yaşlıları ve kadınları öldürmeyin; hurma ağaçlarını kökünden sökmeyin ve yakmayın, meyveli ağaçları kesmeyin, yeme amaçlı dışında koyun, sığır ve develeri boğazlamayın! Kendilerini manastırlarında ibadete veren bir topluluğa uğradığınızda, onları yaptıkları işleriyle baş başa bırakın! ..." ${ }^{44}$

Hz. Ömer'in (ra), Hz. Sa'd b. Ebî Vakkâs'ı (ra) (öl. 55/675) Irak'ın Fethine gönderirken yaptı̆̆ı vasiyeti de bu türden bir örnektir. ${ }^{45}$

Burada başka bir konuya işaret etmekte fayda vardır; Müslüman kadınların, çocuklarını cihada katılma yönünde teşvik etmeleri, düşmanla karşılaşıllığında sabır ve sebat göstermeleri konusundaki vasiyetleri de bulunmaktadır. Bu kadınlardan birisi de câhiliye döneminde, kardeși Sahr öldürüldügünde acısından mersiyeler yazan ve cahiliye döneminde mersiye şiirleriyle meşhur olan Hansâ'nın (ra) (öl. 24/645) vasiyetidir. Bu kadın İslâm'a girdikten sonra, Hz. Ömer (ra) döneminde yapılan Kâdisiye savaşına giden dört çocuğunu cihada teşvik etmiş, şehit olduklarını öğrendiğinde Allah’a hamd etmiştir. ${ }^{4}$

\section{Toplumsal/ İctimâî Vasiyetler}

$\mathrm{Bu}$ vasiyetlerden maksat nasihat, yol gösterme ve eğitimdir. Babalar ve annelerin hayatta edindikleri tecrübeleri ve birikimlerini, çocuklarına doğru yolu göstermek, toplumsal hayatı öğretmek amacıyla yaptıkları vasiyetlerdir. Bu tür vasiyetler daha çok dünya hayatını düzenlemeye yönelik olmuştur. Bunlar câhiliye döneminde de mevcuttu. ${ }^{47}$ Ancak İslâm'ın gelmesiyle birlikte bu vasiyetler, Kur'an ve Sünnet çerçevesinde sadece dünya ile ilgili kalmayıp, kişiyi her iki cihanda saadete ulaştıracak şekilde genişlemiştir. Ayrıca bu vasiyetler sadece çocuklarla sınırlı kalmayıp toplumun tamamını kuşatacak şekilde genişlemiştir. Kur'ân'ın إِنََّا المُؤْينُونَ إخْوَةُ "Müminler ancak kardeştirler"48 ayeti gereğince, Halifeler bütün insanlara, anne baba sadece kendi çocuklarına değil, diğer bütün Müslümanlara tavsiyede bulunmuşlardır. İslâm toplumunda yaşayanlar bunu kendilerine bir vazife olarak gördüklerinden bu sorumluluğu yerine getirmişlerdir.

Bu türden yapılan vasiyet çeşitlerinin örnekleri kaynaklarda bir hayli fazladır. Onlardan bir tanesi Hz. Ali'nin (ra) oğlu Hz. Hasan'a (ra) (öl. 49/670) yaptığı aşağıdaki

43 Buhârî, "Gazvetü'l-Hayber", 605-606; Emîn Düveydâr, Sûverün min hayati'r-resûl (Kahire: Dârü'l-Meâ'rif, 1953), 481-482.

44 Hudarî, İtmâmü'l-vefâ, 43-44.

45 Demirayak, Arap Edebiyatı Tarihi-II, Sadru'l-İslâm Dönemi, S. 240.

46 Vasiyetin tamamı için bk. Dülemî, Cemheratu vesâya'l-Arab, 3/353.

47 Dülemî, Cemheratu vesâya'l-Arab, 2/77.

48 el-Hucurât, 49/10. 


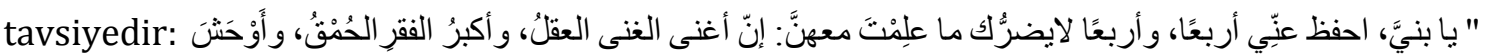

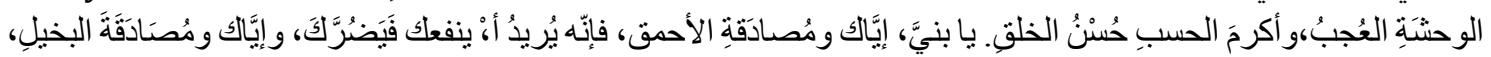

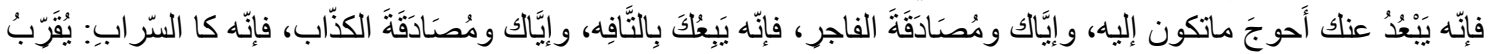

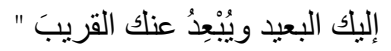

\begin{abstract}
"Yavrucuğum! Benden, kendisiyle amel ettiğin sürece sana zarar vermeyecek dört șey ile birlikte, şu dört şeyi de dinle: Zenginliğin en değerlisi akıl, yoksulluğun en büyüğü ahmaklık, yalnızlı̆̆ın en kötüsü kendini beğenme, hasebin en soylusu güzel ahlaktır. Yavrucuğum! Sakın ahmakla beraber olma, çünkü o, sana fayda vermek isterken zarar verir; sakın cimriyle dost olma, çünkü o, kendisine en ihtiyaç duyduğun anada senden uzaklaşır; sakın ahlaksız biriyle dost olma, çünkü o, seni değersiz bir şeye satar; sakın yalancıyla arkadaşlık etme, çünkü o, sana uzaktakini yakınlaştıran, yakındakini de senden uzaklaştıran serap gibidir." 49
\end{abstract}

Hz. Ömer'in (ra) bütün Müslümanlara olan vasiyeti, ${ }^{50}$ yine Hz. Ebü'd-Derdâ'nın (ra) (öl. 39/660) arkadaşlarına yaptığı vasiyet, ${ }^{51} \mathrm{~Hz}$. Ali'nin (ra) cihadın Cennet kapılarından biri olduğu ile ilgili tavsiyesi, ${ }^{52}$ ve buna benzer daha birçok toplumsal hayatla ilgili yapılan tavsiyeler kaynaklarda mevcuttur. ${ }^{33}$ Câhiliye döneminde, sosyal hayatta evlenecek kızlara, zifaftan önce anneleri bazı tavsiyelerde bulunurdu. Sadrü'l-İslâm Döneminde sadece anneler değil, aynı zamanda bu kervana babalarda katılmış, kız çocuklarına tavsiyelerde bulunmuşlardır.

Ebu'l-Esved ed-Düelî’nin (öl. 69/688) kızına yaptığı vasiyet bu türdendir. 0 gelin

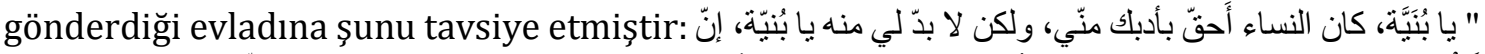

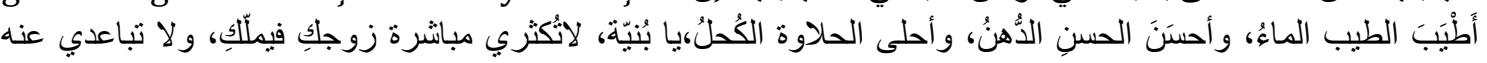

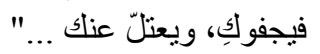

"Ey kızım! Kadınlar senin edebine benden daha layıktır. Fakat o da benim için kaçınılmaz. Kızım! Temizlerin en temizi sudur. Güzellerin en güzeli de kokudur, süslerin en güzeli sürmedir. Kızım! Kocanın üzerine çok düşme ki senden bıkmasın, ondan çok da uzak durma ki senden kaçıp da sana mazeret göstermesin..."54

Babaların evlatlarına bu türden tavsiyelerde bulunmaları, İslam'ın aile hayatına verdiği önemin bir neticesi olup, ebeveynlerin bu konudaki hassasiyetlerinden kaynaklanmaktadır.

\title{
7. Ticarî Münasebetlerle İlgili Vasiyetler
}

Bu türden vasiyetler günlük hayatta insanın hayatın kazanmak için çalışıp çabaladığı alım satımın bütün alanlarıyla ilgili olup, bu konuda kimsenin zarar görmemesi, herkesin hak ettiği kadar kazanması ve bu konuda en ideal yolu belirlemek için yapılan vasiyet

\footnotetext{
49 Demirayak, Arap Edebiyatı Tarihi-II, Sadru'l-İslâm Dönemi, 1/241-242.

50 Bkz. İbn Münkız, Lübâbi'l-âdâb, 12.

51 Dülemî, Cemheratu vesâya'l-Arab, 2/319; İbn Münkız, Lübâbi'l-âdâb, 16.

52 Câhiz, el-Beyân ve't-tebyîn, 2/35-36.

53 Daha detaylı vasiyetler için bkz. el- Câhiz, el-Beyan ve't-tebyîn; Dülemî, Cemheratu vesaya'aArab; İbn Münkı, Lübâbi'l-âdâb.

54 Dülemî, Cemheratu vesâya'l-Arab, 2/147-148; İpek, Klasik Dönem Arap Edebiyatında Nesir, 9596.
} 
çeşitleridir. Bu konuda önder Hz. Muhammed'dir (sav). Onun bu konuda sayısız tavsiyesi vardır. Bunlardan birisinde bir defasında Medine pazarına uğramış, çarşıda buğday satan birinin yanına giderek sattığı malı denetlemiştir. Malın istenilen vasıfta olmadığını görünce

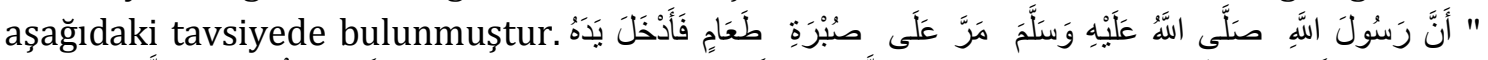

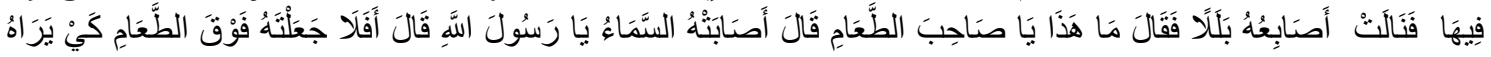
“Hz. Peygamber bir gün, bir buğday yığınının yanına uğramış, elini buğdayın içine soktuğunda parmaklarına sslaklık dokunmuştu. Bunu üzerine sahibine, bu ne diye? sordu. Buğday sahibi; onu yağmur ıslattı, ey Allah'ın elçisi! deyince Peygamberimiz; o ıslak kısmı, insanların görmesi için üste çıkarsaydın ya aldatan benden değildir" 55 diye buyurdu. Yine bu türe örnek olarak Hz. Ebubekir'in (ra) elbise alışverişi yapan kölesine yaptığı tavsiyesidir. Hz. Ebubekir (ra) bu alışverişi yapan kölesine aşağıdaki tavsiyede

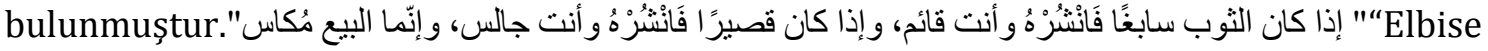
uzun ise; onu ayakta aç, kısa ise onu otururken aç, muhakkak ki satış tahsil etmektir."

\section{Sadrü'l-İslâm Dönemi Vasiyetlerin Genel Özellikleri}

1-Sadrü'l-İslâm dönemi vasiyetlerinde dil basit ve anlaşllır, cümleler kısa ve öz olarak söylenmiştir. Çoğu vasiyetler sözlü olarak söylenmiş olsa da kelimeler özenle seçilmiş kulağı rahatsız edecek lafızlara yer verilmemiştir.

2-Vasiyetlerde hitap, samimi ve içtendir.

3-Verilen tavsiyeler kendi içerisinde bir bütünlük oluşturmaktadır.

4-Vasiyetlerde bilgi ve tecrübelerin aktarımı yansıra dıș dünyaya yön verme amacı da taşıdığı sonucu vardır.

5-Vasiyetlerde haberi cümlelerin yanı sıra inşâ'i cümleler de kullanılmıștır. ${ }^{57}$

6-Vasiyetler genelde kısa ve özdür. Hz. Ebubekir (ra) Yezîd b. Ebî Süfyân'ı (ra) (öl. 18/639) Şam'ı fethetmek için gönderdiğinde yaptığı vasiyet buna örnektir. "Askerlerine nasihat edeceğin zaman; kısa tut, zira çok sözün bir kısmı bir kısmını unutturur."

\section{Sonuç}

Vasiyet, İslâm öncesi Câhiliye Arapları tarafından bilinen bir edebiyat türüdür. İslâm geldikten sonra da Arapların edebiyatını ret ve inkâr etmemiş, kendi ilkeleri doğrultusunda ona yön vererek daha da gelişmesine katkıda bulunmuştur.

Sadrü'l-İslâm döneminde vasiyetler, Kur'an ve Hz. Peygamber (sav) öncülüğünde en parlak dönemini yaşamıştır. Hz. Peygamber'den (sav) sonrada Raşit Halifeler, İslâm coğrafyasının da genişlemesiyle beraber vasiyet geleneğini devam ettirip, vasiyetlerin çeşitlenmesine katkıda bulunmuşlardır.

\footnotetext{
55 Müslim, “İman”, 43.

56 Dülemî, Cemheratu vesâya'l-Arab, 2/465.

57 Fidan, Klasik Arap Edebiyatında öğ̈̈tler, 16-19.

58 İpek, Klasik Dönem Arap Edebiyatında Nesir, 93.
} 
İslâm'ın İlk döneminde yapılan vasiyetler, dini, siyasi, askerî, ekonomik ve toplumsal vasiyetler olmak özere beş ana başlık altında gelişmiştir.

Bu dönemdeki vasiyetler, şekil olarak Câhiliye dönemindekilerle paralel yönde devam etmiş, ancak içerik olarak İslâm'ın ilkeleri doğrultusunda zengin bir içeriğe kavuşmuştur. Bu dönemde de vasiyetler genellikle Câhiliye döneminde olduğu gibi kısa ve irticali olarak yapılagelmiştir. 


\section{Kaynakça}

Abdüllatîf, Abdüşşâfî Muhammed. Âsru'n-nübüvve ve'l-hilâfet'r-râşide. Kahire: Şerîketü's-Sefîr, ts.

Buhârî, Ebû Abdillâh Muhammed b. İsmâîl b. İbrâhîm el-Cu'fî. el-Câmi'u's-sahîh. İstanbul: elMektebetü'l- İslamî, 1979.

Câhiz, Ebû Osmân Amr b. Bahr b. Mahbûb el-Kinânî. el-Beyân ve't-tebyîn. 4 Cilt. Beyrut: Dârü'lKütübi'l-İlmiyye, 2009.

Demirayak, Kenan. Arap Edebiyatı Tarihi-II, Sadru'l-İslâm Dönemi. Erzurum: Fenomen Yayınları, 2017.

Düveydâr, Emîn. Sûverün min Hayati'r-Resûl. Kahire: Dârü'l-Meâ'rif, 1953.

Dülemî, Muhammed Nâyıf. Cemheratu vesâya'l-Arab. 3 Cilt. Beyrut: Dârü'n-Nidâl, 1991.

Ebû Dâvûd, Süleyman b el-Eş'as b İshak es-Sicistani el-Ezdi. es-Sünen. Beyrut: Dâr İhyâü's-Sünneti'nNebeviyye, 1988.

Ezherî, Muhammed b. Ahmed. Tehzîbü'l-luga. thk. Abdusselâm Muhammed Hârûn. 16 Cilt. Kahire: Mektebetü'l-Hâncî,1976.

Ferrûh, Ömer. Târîhu'l-edebi'l-arabî. 6 Cilt. Beyrut: Dârü'l-I'l'Im Lil'melâyîn, 4. Basım, 1981.

Fığlalı, Ethem Ruhi. "Hâricîler". 16/169-175. İstanbul: Türkiye Diyanet Vakfı Yayınları, 1997.

Fidan, İbrahim. Klasik Arap Edebiyatında öğütler. Ankara: Gece Kitaplı̆̆ı, 2017.

Fîrûzâbâdî, Muhammed b. Ya'kûb. el-Kâmûsü'l-muhît. thk. Yusûf el-Bîkâî. Beyrut: Dârü'l-Fikr, 1995.

Hafâcî, Muhammed Abdulmun'im. el-Hayâtü'l-edebiyye ba'de zuhûri'l-İslâm. Beyrut: Dârü'l-Cîl, 1990.

Hafâcî, Muhammed b. Abdilmün'im. el-Hayâtü'l-Edebiyye fi'l-'Asri'l-Câhilî. Beyrut: Dârü'l-Cîl, 1992.

Hudarî, Muhammed. İtmâmü'l-vefầ fí sîreti'l-hulefâ. Dımaşk: Dâr ibn kesîr, 2. Basım, 1997.

İbn Münkız, Ebü’l-Hâris Necmüddîn Üsâme b. Mürşid b. Alî b. Mukalled b. Lübâbi'l-âdâb. Mısır: elMatba'tü'r-Rahmâniyya, 1953.

İpek, Muhammed Selim. Klasik Dönem Arap Edebiyatında Nesir. Gece Kitaplığı, 2015.

İsfahânî, Ebü'l-Ferec Alî b. el-Hüseyn b. Muhammed b. Ahmed el-Kureșî el-. el-Eğâni. 25 Cilt. Kahire: Dâru İhyâü't-Türâsi'l-Ârabî, 1963.

Matpan, Ebubekir. "Arap Edebiyatında Tevkî'ât (Sadru'l-İslâm Dönemi)". Mesned İlahiyat Araştırmaları Dergisi 12/1 (30 Haziran 2021), 75-92.

Müberred, Ebu'l-Abbas Muhammed b. Yezid. el-Kâmil fi'l-edeb. 2 Cilt. Kahire: Dârü'l-Fikri'l-Ârabî, 1997.

Müslim, Ebü'l-Hüseyn Müslim b. el-Haccâc b. Müslim el-Kuşeyrî. el-Câmi'u's-sahîh. 5 Cilt. Beyrut: Dâru İhyâi'l- Kütübi'l-Arabiyye, 1991.

Temr, Ali Hüseyin Muhammed. "el-Vesâyâ fî asr sadri'l-İslâm". Mecelltü câmiat Tikrît li'l-ulûm 20/1 (2012), 206-245.

Tirmizî, Ebû Îsâ Muhammed b. Îsâ b. Sevre. el-Câmi u's-sahîh. Kahire: Dârü'l-Meâ'rif, 1975.

Ürün, Ahmet Kâzım. Klasik Arap Edebiyatı. Konya: Çizgi Kitapevi, 2015. 